\title{
What Happens after the Gap?- Size Distributions of Patches with Homogeneously Sized Trees in Natural and Managed Beech Forests in Europe
}

\author{
L. Drössler1 ${ }^{*}$, E. Feldmann², J. Glatthorn², P. Annighöfer ${ }^{3}$, S. Kucbel, V. Tabaku ${ }^{5}$ \\ ${ }^{1}$ Southern Swedish Forest Research Centre, Swedish University of Agricultural Sciences, Alnarp, Sweden \\ ${ }^{2}$ Institute of Plant ecology and Ecosystem Research, University of Göttingen, Göttingen, Germany \\ ${ }^{3}$ Department of Silviculture and Forest Ecology of the Temperate Zones, University of Göttingen, Göttingen, \\ Germany \\ ${ }^{4}$ Institute of Silviculture, Faculty of Forestry, Technical University of Zvolen, Zvolen, Slovakia \\ ${ }^{5}$ Chair of Silviculture and Forest Ecology, Agricultural University of Tirana, Tirana, Albania \\ Email: "Lars.drossler@slu.se
}

Received 28 December 2015; accepted 29 May 2016; published 2 June 2016

Copyright (C) 2016 by authors and Scientific Research Publishing Inc.

This work is licensed under the Creative Commons Attribution International License (CC BY).

http://creativecommons.org/licenses/by/4.0/

(c) (i) Open Access

\section{Abstract}

A novel but simple approach for describing stand structure in natural and managed forests driven by small-scaled disturbances is introduced. A primeval beech forest reserve in Slovakia and two beech stands in Germany with different management histories were studied, and their forest stand texture was analysed in terms of tree coordinates, stem diameter, and crown radius. Neighbouring trees of similar size with estimated contact of their crowns were assigned to tree groups. The study goal was to estimate the number and size of such homogeneous patches. In all cases, the number of tree groups in a particular diameter class decreased exponentially as group size increased. Single trees were predominant. Compared to simulated random tree distributions, the natural stand exhibited a more clumped distribution of small trees and more regular distribution of larger ones. The natural forest generally had smaller groups than the managed even aged stand, but the smallest group sizes were found in the uneven-aged selection forest. The simple analytical approach provided new spatial insights into neighbourhood relations of trees. The continuous scale from single trees to larger tree groups is an important achievement compared to other analytical methods applied in this field. The findings may even indicate a certain degree of selforganization in natural forests. Due to the limitations associated with each method or statistical models, a joint consideration of 1) gap dynamics, 2) forest developmental stages, and 3) size

\footnotetext{
Corresponding author.
}

How to cite this paper: Drössler, L., Feldmann, E., Glatthorn, J., Annighöfer, P., Kucbel, S., \& Tabaku, V. (2016). What Happens after the Gap? - Size Distributions of Patches with Homogeneously Sized Trees in Natural and Managed Beech Forests in Europe. Open Journal of Forestry, 6, 177-190. http://dx.doi.org/10.4236/ojf.2016.63015 
classes of homogeneous tree groups is recommended. Relevant to forest practitioners, the size class distributions enhance an understanding of the complex stand structures in natural forests and therewith support an emulation of natural forest dynamics in managed beech forests.

\section{Keywords}

Forest Structure, Natural Forest Dynamics, Tree Neighbourhood Relationships,
Close-to-Nature Management, Fagus sylvatica, Central Europe

\section{Introduction}

\subsection{Background of the Study}

Forest ecosystems are complex and adaptive, with the ability to adjust and react to changing conditions (Messier et al., 2014). For instance, light and microclimate influence various processes in beech forest ecosystems, affecting their regeneration performance and growth of individual trees (Madsen \& Larson, 1997; Wagner, 1999; Bartsch et al., 2002; Pretzsch, 2009). These processes are also influenced by other factors such as stand structure. Because natural stand structures provide certain advantages in terms of resilience and genetic adaptability, they are increasingly regarded as a viable option for the management of beech stands (Finkeldey \& Ziehe, 2004; Röhrig et al., 2006; Brumme \& Khanna, 2009). The paradigm of “Close-to-Nature Forest Management” (CNFM) was developed to exploit these benefits. CNFM is widely used in Central Europe and can be implemented in conjunction with a wide range of silvicultural methods focusing on single trees and tree groups (Duncker et al., 2012; Brang et al., 2014; Bauhus et al., 2014). However, it is impossible to perfectly reproduce natural forest structures in a managed stand since by definition, natural forest is not managed (Leibundgut, 1993).

F. sylvatica would be the dominant species in large parts of Central Europe in the absence of human influence (Ellenberg, 1996). Due to the human impact, however, only a small proportion of Central European forests are remnant natural beech forests. In this study, we compare two managed beech stands in Germany to one of the closest remaining natural beech forest reserves below 800 m elevation: the reserve Kyjov in Slovakia. The purpose of the study was to enhance the understanding of forest dynamics in beech ecosystems by determining frequency distributions of patches (tree groups) with neighbouring trees of similar size. Another aim was to support forest managers who want to develop natural stand structures and wilderness-like areas (i.e. the Sihlwald near Zurich in Switzerland, or the National Park Hainich in Germany).

The following section provides an overview of established methods for analysing stand structure and dynamics of natural European beech forests. Later, the novel approach for describing and comparing the aggregation of similarly-sized trees in forests is presented.

\subsection{Silvicultural Research in Natural Beech Forests in Europe}

Natural stand structures have been of interest to foresters since the late 19th century (see Brang, 2005 for an overview). Older studies described both more heterogeneous and homogeneous types of stand structure in natural beech forests (Fröhlich, 1925; Müller, 1929; Gehrhardt, 1923). More recent studies emphasized the prevalence of heterogeneous stand structures (Tabaku, 2000; Meyer et al., 2003; Commarmot et al., 2005).

Smith et al. (1997) defined the internal forest structure in terms of tree species composition, age classes, stand layers, and diameter distributions. Helms (1998) distinguished between vertical and horizontal forest structures. The horizontal structure of the forest is the spatial arrangement of its vertical structures, i.e. the forest texture. Later structural analyses also considered the abundance of dead wood or other micro-habitats (i.e. Winter \& Brambach, 2011).

To analyse the forest texture (as one aspect of horizontal structure on the patch scale), development stages and phases have been defined in terms of typical stand structures (Leibundgut, 1993; Korpel, 1995; Meyer, 1999). For example, Neumann (1979), Leibundgut (1993) and Korpel (1995) identified and mapped developmental stages in the forest. Later, other methods were developed to ensure that the results of structure analyses were reproducible (Meyer, 1999; Tabaku, 2000; Drössler \& Meyer, 2006). However, all of these methods failed at 
identifying true borders between developmental stages because they assigned development stages and phases to defined forest patches of certain size using relatively coarse rasters. This may bias the estimation of the area of each stage, especially for smaller units. In addition, the raster approach can fail to detect overlapping stages (Korpel, 1995; Drössler \& Meyer, 2006), as shown by Grassi et al. (2003). A more advanced mapping of developmental phases in a natural spruce-fir-beech forest was presented (Kral et al., 2010), which also included dead trees. In addition, irregular patches (usually $400-1100 \mathrm{~m}^{2}$ in size) with spatially distinct stand characteristics (tree number, standing volume, deadwood) were indicated by statistical models (Kral et al., 2014).

Direct information about the area and spatial distribution of initial development phases can be gained from canopy gap studies (e.g. Runkle, 1992; Zeibig et al., 2005; Nuske, 2006) or extensive dendrochronological studies (Šamonil et al., 2013). Terrestrial gap surveys typically use measurements of tree heights or diameters at breast height $(\mathrm{DBH})$ to distinguish between gaps and adjacent stands (Runkle, 1992). DBH data were also analysed by Tabaku and Meyer (1999), who created stand maps based on modelled tree crowns and identified canopy gaps in beech forests based on the absence of trees of $\geq 7 \mathrm{~cm}$ DBH. Drössler and von Lüpke (2005) used higher DBH thresholds in a similar way $(20$ and $30 \mathrm{~cm}$, respectively) to study gaps in the upper canopy layer.

If the initial gap stage is defined using such thresholds, subsequent developmental stages could be estimated by focusing on particular size classes of trees. Neighbouring trees of approximately the same size could then be regarded as groups representing one stage of development. This idea is similar to that presented by Grassi et al. (2003), who distinguished between developmental stages on the basis of tree height and growth-related parameters. Although it is difficult to equalize diameter and development stage (Piovesan et al., 2005; Kral et al., 2010; Trotsiuk et al., 2012; Šebkova et al., 2012), we followed this idea to gain more insights into the interactions of fine-scale neighbourhood processes and coarser-scale forest dynamics. Thereby, we went beyond the scope of conventional forest structure indicators and sophisticated point pattern correlations (von Gadow et al., 2012) that oversimplifyied forest structure from a management point of view. Especially the flexibility to summarize exponentially decreasing numbers of patches with increasing patch size was desired when the presented simple analytical method was developed.

The goal of this study was to identify tree groups and describe their size in terms of the number of individuals belonging to a group. Study objects were forests of different management intensity. Main objective was to determine how frequently trees of particular size classes are aggregated in groups. Hopefully, size distributions of such tree groups could point out general stand dynamic patterns, from the initiation to the terminal phase. Also, comparisons of individual-based stand structure between natural and managed forests (especially those managed in a "close to nature" fashion) could be made. Finally, the comparison of observed and randomized tree distributions could link ecological field studies better with hypothetical spatio-temporal models (Gratzer et al., 2004).

Since the abundance of canopy gaps in natural beech forests decreases exponentially with increasing gap size (Zeibig et al., 2005; Drössler, 2006), we hypothesized that the number of tree groups within a given size class would decrease exponentially with increasing tree size. We also hypothesized that the spatial arangement of tree groups would not be random. In addition to these two hypotheses, we addressed management history and cutting regime by assessing their effect on the size distribution of tree groups.

\section{Material and Methods}

\subsection{Study Sites}

The stand characteristics and structure of the examined stands were already chosen in two extensive studies that documented of beech forest stands with different management intensity (Tabaku, 2000; Drössler, 2006). Within these studies, field data were collected in the Kyjov natural forest reserve in eastern Slovakia, in an uneven-aged single-tree selection stand (Plenterwald) in Bleicherode, and in an even-aged stand in Stauffenburg managed by target diameter cutting. The latter two stands are both located in central Germany. Stand sizes ranged from 22 to 50 ha. The basal area proportion of European beech was 99\% in Kyjov and Bleicherode, and 97\% in Stauffenburg. The stand top height in Stauffenburg was $38 \mathrm{~m}$ at an age of 166 years. The top heights in Kyjov and Bleicherode were estimated to be $30 \mathrm{~m}$ and $33.5 \mathrm{~m}$, respectively. All three sites were moist-mesic and fertile. The uneven-aged stand at Bleicherode has been managed by single-tree selection for more than 140 years. In Stauffenburg, the trees have been harvested on reaching a target diameter (Table 1) for several decades. The Kyjov reserve is one of the last remaining natural beech forests in central Europe at sub-montane elevation, and one of the closest to the German study sites. Its altitude is $400 \mathrm{~m}$ greater than that of the German sites (Table 1), and it 
Table 1. Site and stand characteristics of the studied stands in Slovakia (Kyjov) and Germany (Bleicherode, Stauffenburg).

\begin{tabular}{cccc}
\hline & Kyjov & Bleicherode & Stauffenburg \\
\hline Latitude & $48^{\circ} 51^{\prime}$ & $51^{\circ} 16^{\prime}$ & $51^{\circ} 21^{\prime}$ \\
Longitude & $22^{\circ} 01^{\prime}$ & $10^{\circ} 20^{\prime}$ & $10^{\circ} 05^{\prime}$ \\
Altitude & $700-800 \mathrm{~m}$ & $420-440 \mathrm{~m}$ & $300-350 \mathrm{~m}$ \\
Mean annual precipitation & $750-800 \mathrm{~mm}$ & $650-730 \mathrm{~mm}$ & $780-900 \mathrm{~mm}$ \\
Mean annual temperature & $6^{\circ} \mathrm{C}$ & $7^{\circ} \mathrm{C}$ & $7.5^{\circ} \mathrm{C}$ \\
Base rock & Andesite & Limestone & Sandstone \\
Soil type & Cambisol & Leptosol & $38.4 \mathrm{~m}$ \\
Top stand height & $30 \mathrm{~m}$ & $33.5 \mathrm{~m}$ & 166 yrs. \\
Stand age & uneven & uneven & Target diameter cutting \\
Harvest method & Never managed & Single-tree selection & 7.25 ha \\
Study plot size & 12 ha & 7.5 ha & 663 \\
\hline
\end{tabular}

has not been subjected to any silvicultural management. Korpel (1995) reported an annual periodic increment of $6.5 \mathrm{~m}^{3} \cdot \mathrm{ha}^{-1}$, ranging from 3 to $12 \mathrm{~m}^{3} \cdot \mathrm{ha}^{-1} \cdot \mathrm{a}^{-1}$ depending on the developmental phase. Tabaku (2000) and Drössler (2006) describe also forest floor vegetation, soil conditions, and other features of the studied stands.

\subsection{Data Sampling}

One representative plot covering 7 - 12 ha was established in the centre of each stand. The plots in Bleicherode and Stauffenburg were measured by Tabaku (2000) in 1997. The plot in Kyjov was measured in autumn 2003. The measuring procedure and the methods applied were identical during all measurements. All living trees with a diameter at breast height $(\mathrm{DBH}) \geq 7 \mathrm{~cm}$ were recorded in each study stand. The coordinates of these trees were measured by distance and angle from a $31.25 \mathrm{~m}$ grid, and their DBH values were calipered. The tree heights and 8 crown radii per tree were measured for 30 - 60 trees covering the DBH range in each stand. Established correlations between DBH and mean crown radius were used to assign a circular crown to every tree (see Tabaku, 2000; Drössler, 2006).

\subsection{Data Analysis and Determination of Tree Groups}

DBH distributions were calculated for each of the three stands on the basis of $4 \mathrm{~cm}$ wide DBH classes. In order to identify tree groups containing trees of similar size, all trees were assigned to DBH classes with widths of 10 $\mathrm{cm}$. In addition, for a sensitivity analysis of the results, tree groups were also defined on the basis of DBH classes with widths of $20 \mathrm{~cm}$.

Maps showing the spatial arrangement of trees in a given size class and their allotted crowns were used to identify tree groups (Figure 1). All trees having a crown contact with a neighbouring tree of the same size class were considered to be part of the same group as the contacted tree. Thus, each group represents a collection of similarly sized trees in which the mean crown radius is used as a boundary limit for defining neighbouring and non-neighbouring trees (i.e. trees whose crowns do and do not touch, respectively). Finally, the frequency of these differently sized groups was determined and exponential regression models were fit to the frequency data. In addition, a random distribution of the recorded tree diameters over the sample area was simulated and compared to the tree group frequencies observed in reality. In 1000 simulations the spatial position of each tree was changed by randomly assigning new $\mathrm{x}$ - and $\mathrm{y}$-coordinates to each tree within the borders of the original stands. Total stem count and DBH distributions stayed the same. Borders of the $95 \%$ confidence intervals of group frequencies were determined by the 0.025 and 0.975 quantiles of the group size frequency distributions of the simulations.

The bootstrap Kolmogorov-Smirnoff two-sample test was used to identify statistically significant differences 


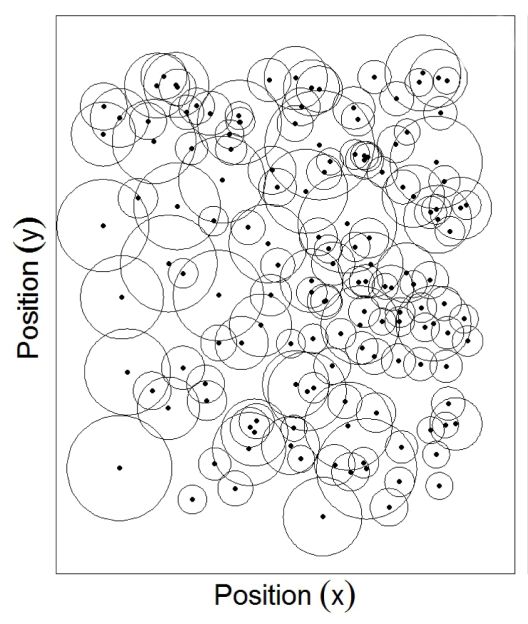

(a)

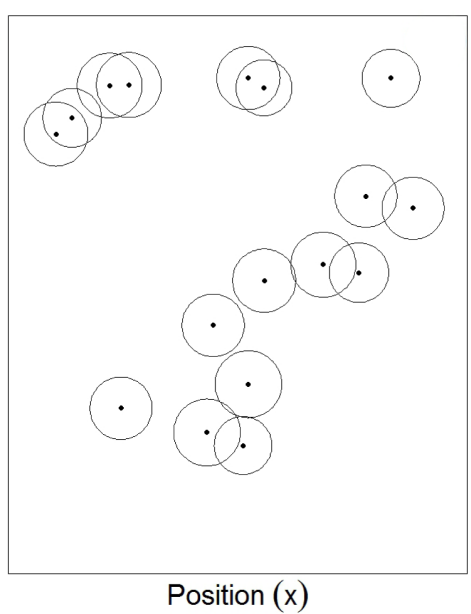

(b)

Figure 1. A section of one of the crown maps used in the analysis ((a): all trees $\geq 7 \mathrm{~cm} \mathrm{DBH}$; (b): trees of DBH class 37 - 47 $\mathrm{cm})$.

between the tree group frequencies in the natural stand and the managed stands. Significant differences between the tree distributions of the simulations and the empirically observed stands were identified by means of the Kolmogorov-Smirnoff statistic D. D was calculated for each of the 1000 simulated and the empirical stands by comparing their distribution functions with the distribution function of the arithmetic mean of all of the simulations. The p-value was determined by the fraction of simulated stands with a D-value higher than the one of the respective empirical stand. All tests were performed with a confidence level of 0.95. Tree group frequency comparisons were performed for each DBH class separately.

In addition, sensitivity analyses were conducted. The sensitivity of the results to variation in the definition of crown size was tested by increasing the crown diameters used to define neighbouring trees by $10 \%$ and $20 \%$. Secondly, instead of the total sample area, 20 systematic sample plots $(62.5 \mathrm{~m} \cdot 62.5 \mathrm{~m})$ within the original data from Kyjov were tested to assess edge effects and to be facilitate comparison of the results obtained to those presented for a different forest reserve (Drössler, 2006).

\section{Results}

\subsection{Diameter Distributions}

The largest tree observed in this work was growing in the natural forest and had a DBH of $121 \mathrm{~cm}$. Figure 2 shows that in the natural forest, trees in the first two DBH classes were the most abundant, and that the number of trees in each class declined exponentially with increasing $\mathrm{DBH}$ after the second class. However, the rate of decline was relatively modest on going from 30 to $110 \mathrm{~cm}$ DBH. In managed forests, the diameter range was smaller and the maximum observed DBH values were 87 and $74 \mathrm{~cm}$ for the uneven- and even-aged stand, respectively. The even-aged stand exhibited the bell-shaped DBH distribution typical of such management regimes, with diameters ranging from $26-74 \mathrm{~cm}$ and a mean DBH of around $50 \mathrm{~cm}$. The uneven-aged managed stand was characterized by a more even decline in tree number with increasing tree size compared to the unmanaged forest, with a very steep decline from 12 to $24 \mathrm{~cm}$ and a fairly steady number of trees having DBH values of 40 to $65 \mathrm{~cm}$ (Figure 2).

\subsection{Tree Group Frequencies in the Natural Forest}

$31 \%$ of the measured trees had no neighbouring trees belonging to the same DBH class. Single trees (representing the smallest group size) dominated the group size distributions, and in general there was an exponential decline in the number of groups as the group size increased for all DBH classes. For example, 258 single trees, 99 two-tree groups, and 15 large groups with 15 - 36 trees were identified for the smallest DBH class in Kyjov (Figure 3(a)). Larger DBH classes contained fewer tree groups. The $77-86.9 \mathrm{~cm}$ DBH class included 54 single trees, 10 two-tree groups, and two groups with three trees (Figure 3(i)). 


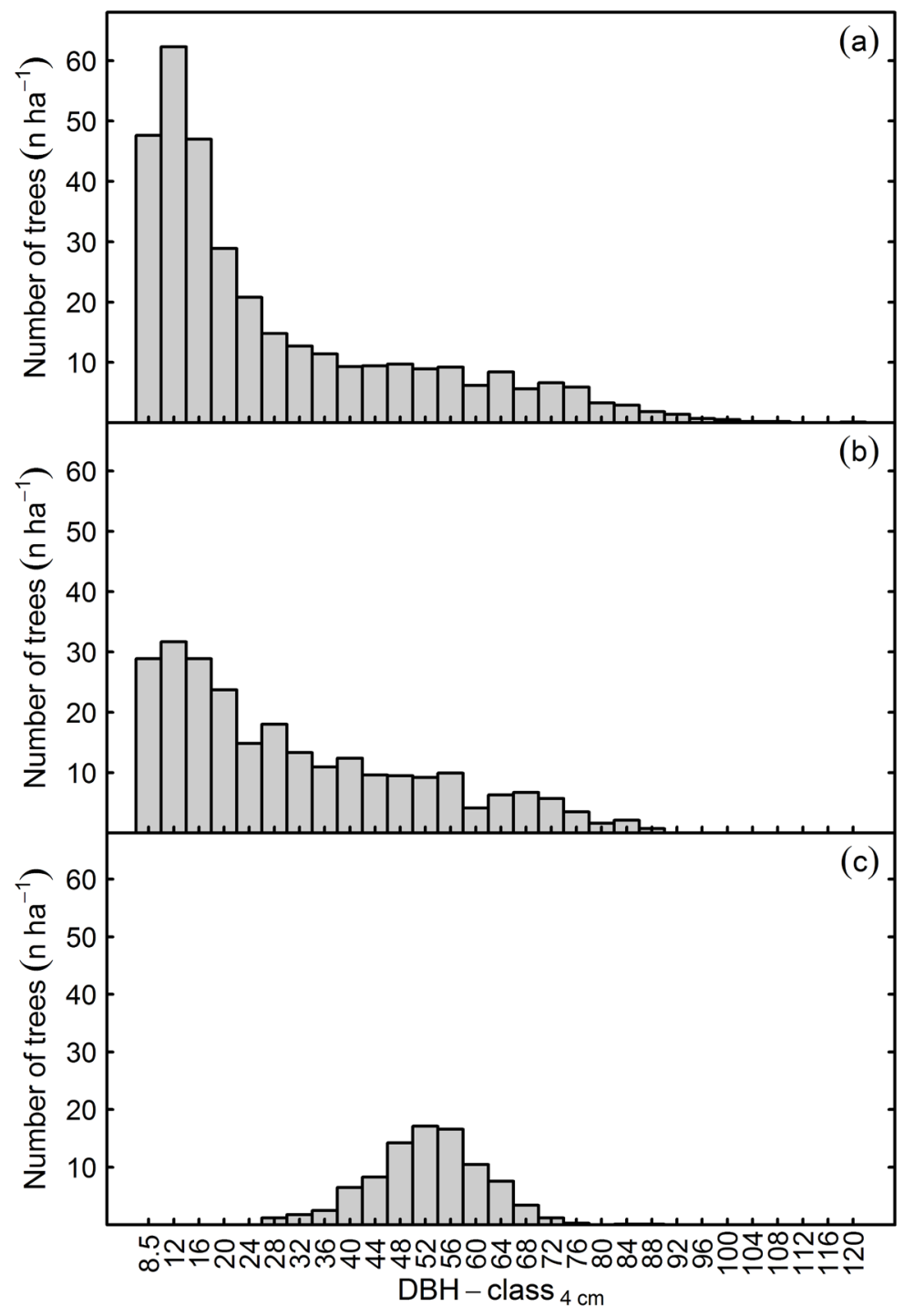

Figure 2. Diameter distributions in (a) the natural forest Kyjov; (b) the uneven-aged managed forest Bleicherode; and (c) the even-aged managed forest Stauffenburg.

Trees in smaller DBH classes occurred more often in groups than was observed in simulated random spatial tree distributions (Figures 3(a)-(c)). We found statistically significant differences between the actual and random distributions of smaller DBH classes (Figures 3(a)-(e)), but not for the largest classes with the fewest trees. Trees in the larger classes were more likely to occur as single trees than would be expected based on a random distribution. However, the differences were not significant for neither of the DBH class widths $(10 \mathrm{or} 20 \mathrm{~cm})$ or the enlarged crown radii in the sensitivity analysis.

\subsection{Tree Group Frequencies in the Managed Forests}

In the managed stands, the number of groups also decreased exponentially with group size. Across all DBH classes, the proportion of single trees (32\%) in the uneven-aged single-tree selection stand was comparable to that in the natural forest. The smallest DBH class $(7-17 \mathrm{~cm})$ in the uneven-aged stand contained 215 single trees, 57 two-tree groups and seven larger groups with 15 - 31 trees, meaning that the number of single trees in this class was somewhat lower than in the natural forest whereas the number of larger groups was greater (Figure 3(a) and Figure 3(j)). The group size distributions for this DBH class in the single tree selection stand differed significantly from the natural forest, as was the case for all other DBH classes except the 27 to $37 \mathrm{~cm}$ 


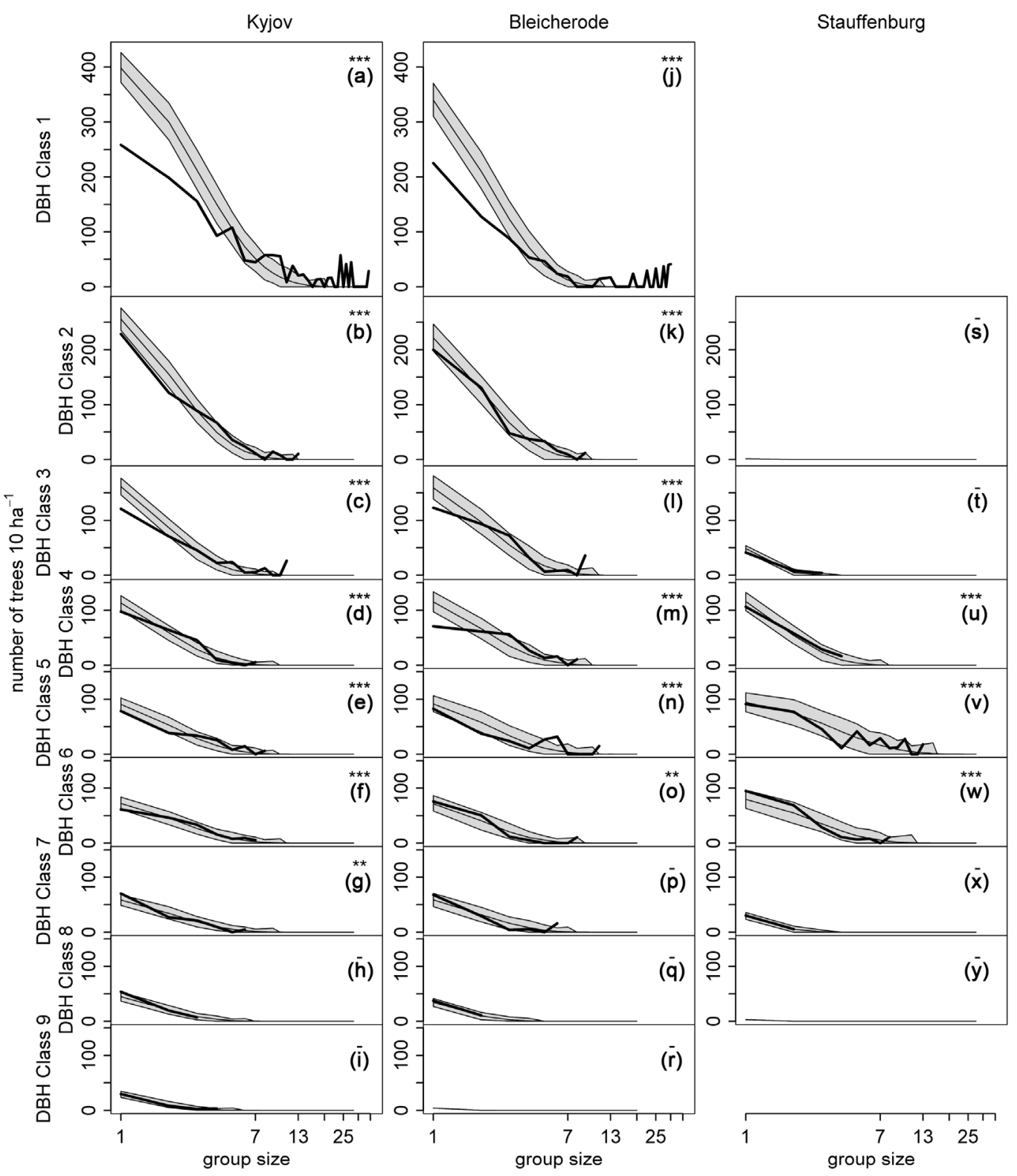

Figure 3. Observed (black line) and expected (grey) group size distributions for different DBH classes in Kyjov ((a)-(i)), Bleicherode ((j)-(r)) and Stauffenburg ((s)-(y)). The y-axis shows the number of trees in groups of the same size, for an imaginary forest compartment of 10 ha size. The logarithmic $\mathrm{x}$-axis indicates the group size which is determined by groups of trees with crown contact. The observed empirical distributions were compared to random distributions of trees (with $95 \%$ confidence interval highlighted in grey). The star symbols denote statistically significant differences at 90, 95, 99 and $99.9 \%$ confidence levels (“.”, “*”, “**”, “***”). For sample sizes of less than 50 no significances are given (“-”).

and the 67 to $77 \mathrm{~cm}$ classes. For tree sizes below $57 \mathrm{~cm} \mathrm{DBH}$, the selection stand contained fewer small tree groups than would be expected from a random distribution. Differences were significant except for the 27 to 37 cm class where the p-value was 0.09. Larger trees with a DBH above $57 \mathrm{~cm}$ seemed to occur slightly more often in smaller groups and less often in bigger groups compared to the random stands. However, differences were only significant for the 67 to $77 \mathrm{~cm}$ class in the sensitivity analysis with enlarged crown radii. One major difference between these two stands was the narrower DBH range of the latter. In addition, the managed stands contained fewer trees and tree groups than the natural forest. Single frequency values of tree groups per size class are shown in the Table 2 and Table 3 for those two study stands. Across all $10 \mathrm{~cm}$ wide DBH classes, the single-tree selection stand was broadly similar to that of the unmanaged forest, compared to the even-aged stand. 
Table 2. Natural forest Kyjov: Number of tree groups on 10 ha (total tree number is 3226 trees). Trees in each group belong to one DBH class. Grouping criterion is the estimated crown contact (see Section 2.3).

\begin{tabular}{|c|c|c|c|c|c|c|c|c|c|c|}
\hline \multirow{2}{*}{$\begin{array}{l}\text { Group size } \\
\text { (Number } \\
\text { of trees } \\
\text { per group) }\end{array}$} & \multicolumn{9}{|c|}{ DBH classes $[\mathrm{cm}]$} & \multirow{2}{*}{$\begin{array}{l}\text { Total number } \\
\text { of trees } \\
\text { in that } \\
\text { group size }\end{array}$} \\
\hline & $7-16.9$ & $17-26.9$ & $27-36.9$ & $37-46.9$ & $47-56.9$ & $57-66.9$ & $67-76.9$ & 77 - 86.9 & $\geq 87$ & \\
\hline 1 & 258.4 & 228.8 & 120.8 & 97.6 & 78.4 & 61.6 & 70.4 & 53.6 & 29.6 & 999 \\
\hline 2 & 99.2 & 60.8 & 35.2 & 32.0 & 19.2 & 23.2 & 13.6 & 9.6 & 4.0 & 594 \\
\hline 3 & 52.0 & 29.6 & 15.2 & 15.2 & 11.2 & 11.2 & 7.2 & 2.4 & 0.8 & 434 \\
\hline 4 & 23.2 & 16.8 & 5.6 & 2.4 & 6.4 & 4.0 & 2.4 & & 0.8 & 246 \\
\hline 5 & 21.6 & 7.2 & 4.8 & 0.8 & 1.6 & 1.6 & & & & 188 \\
\hline 6 & 8.0 & 4.0 & 0.8 & & 2.4 & 1.6 & 0.8 & & & 106 \\
\hline 7 & 6.4 & 1.6 & 0.8 & 0.8 & & 0.8 & & & & 73 \\
\hline 8 & 7.2 & & 1.6 & & 0.8 & & & & & 77 \\
\hline 9 & 6.4 & 1.6 & & & & & & & & 72 \\
\hline 10 & 5.6 & 0.8 & & & & & & & & 64 \\
\hline 11 & 0.8 & & 2.4 & & & & & & & 35 \\
\hline 12 & 3.2 & & & & & & & & & 38 \\
\hline 13 & 1.6 & 0.8 & & & & & & & & 31 \\
\hline 14 & 1.6 & & & & & & & & & 22 \\
\hline 15 & 0.8 & & & & & & & & & 12 \\
\hline \multicolumn{11}{|l|}{16} \\
\hline 17 & 0.8 & & & & & & & & & 14 \\
\hline 18 & 0.8 & & & & & & & & & 14 \\
\hline \multicolumn{11}{|l|}{19} \\
\hline 20 & 0.8 & & & & & & & & & 16 \\
\hline 21 & 0.8 & & & & & & & & & 17 \\
\hline \multicolumn{11}{|l|}{22} \\
\hline \multicolumn{11}{|l|}{23} \\
\hline 24 & 2.4 & & & & & & & & & 58 \\
\hline \multicolumn{11}{|l|}{25} \\
\hline 26 & 1.6 & & & & & & & & & 42 \\
\hline \multicolumn{11}{|l|}{27} \\
\hline 28 & 1.6 & & & & & & & & & 45 \\
\hline \multicolumn{11}{|l|}{29} \\
\hline \multicolumn{11}{|l|}{30} \\
\hline \multicolumn{11}{|l|}{31} \\
\hline \multicolumn{11}{|l|}{32} \\
\hline \multicolumn{11}{|l|}{33} \\
\hline \multicolumn{11}{|l|}{34} \\
\hline \multicolumn{11}{|l|}{35} \\
\hline 36 & 0.8 & & & & & & & & & 29 \\
\hline
\end{tabular}


Table 3. Selection forest stand Bleicherode (Plenterwald): Number of tree groups on 10 ha (total tree number is 2516 trees). Trees in each group belong to one DBH class. Grouping criterion is the estimated crown contact (see Section 2.3).

\begin{tabular}{|c|c|c|c|c|c|c|c|c|c|}
\hline \multirow{2}{*}{$\begin{array}{l}\text { Group size } \\
\text { (Number } \\
\text { of trees } \\
\text { per group) }\end{array}$} & \multicolumn{8}{|c|}{ DBH classes [cm] } & \multirow{2}{*}{$\begin{array}{l}\text { Total number } \\
\text { of trees } \\
\text { in that } \\
\text { group size }\end{array}$} \\
\hline & $7-16.9$ & $17-26.9$ & $27-36.9$ & $37-46.9$ & $47-56.9$ & $57-66.9$ & $67-76.9$ & $\geq 77$ & \\
\hline 1 & 214.7 & 184.0 & 145.3 & 78.7 & 78.7 & 61.3 & 34.7 & & 797 \\
\hline 2 & 57.3 & 44.0 & 58.7 & 30.7 & 32.0 & 25.3 & 1.3 & & 499 \\
\hline 3 & 30.7 & 8.0 & 33.3 & 16.0 & 9.3 & 5.3 & & & 308 \\
\hline 4 & 10.7 & & 14.7 & 13.3 & 5.3 & & & & 176 \\
\hline 5 & 6.7 & 1.3 & 9.3 & 6.7 & 2.7 & 2.7 & & & 147 \\
\hline 6 & 4.0 & & 4.0 & 6.7 & 5.3 & 4.0 & & & 144 \\
\hline 7 & & & 2.7 & 4.0 & & 1.3 & & & 56 \\
\hline 8 & & & 1.3 & 1.3 & 1.3 & & & & 32 \\
\hline 9 & 1.3 & & 1.3 & 2.7 & 2.7 & & & & 72 \\
\hline 10 & & & & & 1.3 & & & & 13 \\
\hline 11 & 2.7 & & & & & & & & 29 \\
\hline 12 & 1.3 & & & & & & & & 16 \\
\hline 13 & 1.3 & & 1.3 & & & & & & 35 \\
\hline \multicolumn{10}{|l|}{14} \\
\hline 15 & & & & 1.3 & & & & & 20 \\
\hline \multicolumn{10}{|l|}{16} \\
\hline 17 & 1.3 & & & & & & & & 23 \\
\hline \multicolumn{10}{|l|}{18} \\
\hline \multicolumn{10}{|l|}{19} \\
\hline \multicolumn{10}{|l|}{20} \\
\hline \multicolumn{10}{|l|}{21} \\
\hline \multicolumn{10}{|l|}{22} \\
\hline \multicolumn{10}{|l|}{23} \\
\hline \multicolumn{10}{|l|}{24} \\
\hline 25 & 1.3 & & & & & & & & 33 \\
\hline \multicolumn{10}{|l|}{26} \\
\hline 27 & 1.3 & & & & & & & & 36 \\
\hline \multicolumn{10}{|l|}{28} \\
\hline 29 & 1.3 & & & & & & & & 39 \\
\hline \multicolumn{10}{|l|}{30} \\
\hline 31 & 1.3 & & & & & & & & 41 \\
\hline
\end{tabular}


The tree size distribution for the even aged stand did not differ significantly from that for the random distibutions (Figures 3(s)-(y)). Beside its general lack of small and very large trees, the even-aged stand also exhibited group numbers that declined exponentially with increasing group size. Contrary to the findings in the other two stands, the 47 - 57 cm DBH class contained most of the trees and the largest groups. Within the 10 ha study plot, this class was represented by 91 single trees, 39 two-tree groups, and 11 groups with minimum seven trees of this size per group (Figure 3(v)).

\subsection{Exponential Fits and Sensitivity Analyses}

The exponential regression function $\mathrm{f}(\mathrm{x})=\lambda \cdot \mathrm{e}^{-\lambda \mathrm{x}}(\mathrm{x}=$ number of trees per group) was fitted to the three empirical tree group size distributions presented in Figure 3 , yielding $\mathrm{R}^{2}$ values of $>0.8$. Lower $\mathrm{R}^{2}$ values only occurred when the exponential function was not flexible enough to follow the steep decline of small groups and the flat distribution of large groups. Lambda values of the fitted functions ranged from -0.1 to -1.2 .

Increasing the crown radii used to define the neighbourhood of each tree by $20 \%$ reduced the number of single trees for all size classes and stands by one third, and increased the number of large tree groups. In the natural forest, the number of single trees in the smallest DBH class $(7-17 \mathrm{~cm})$ decreased from 26 to 15 trees per ha while the number of large groups with more than 15 trees rose from one to two per ha.

An analysis of 20 separated systematic sample plots of 0.4 ha each in Kyjov yielded virtually identical group size frequencies to those observed in the initial analysis of a single large 12 ha plot; one difference was that the maximum number of large tree groups in large DBH classes decreased slightly.

\section{Discussion}

\subsection{Natural Forest Structure and Dynamics}

Earlier studies by Zeibig et al. (2005) and Drössler and von Lüpke (2005) described steep exponential declines in the size distributions of canopy gaps in natural beech forests in Europe. The size and shape of canopy gaps influences the initial conditions that govern future stand development. Canopy gaps give rise to tree groups and determine the future stand structure (Oliver \& Larsen, 1996; Muscolo et al., 2014). In addition, closed and open canopies are associated with different stand structures, depending on the stand history (former gaps) and other factors (Schütz \& Saniga, 2011). Concerning former gap sizes, Šamonil et al. (2013) determined disturbance events dendrochronologically in a beech-dominated forest reserve and reported autocorrelations within ranges of 0 - $30 \mathrm{~m}$, and rarely exceeding $60 \mathrm{~m}$.

Our results indicate that neighbouring trees of different sizes dominate the heterogeneous stand structure of natural beech forests. Interestingly, the number of more homogeneously structured stand sections decreased exponentially as their size increased. The number of groups declined exponentially (and in some cases, even more rapidly, exhibiting a reversed J-shaped decline) with increasing group size. The same pattern has been observed in a similar study conducted in a second natural forest reserve in Slovakia even though the initial agents of disturbance (uprooting versus wind-break) were different (Drössler \& von Lüpke, 2005). Such a pattern may be typical for natural beech forests in central Europe, but further studies at other locations would be required to answer this question.

More insights into natural stand dynamics were obtained by comparing the observed group distributions with randomly simulated distributions. Whereas small trees were actually more likely to be aggregated into groups, very large trees were less extensively grouped. The latter indicates the tendency that very large trees are more regularly distributed than randomly. Such a finding could even be interpreted as an indication of a self-organizing process which is on debate in ecological theory (Levin, 2005; Solé \& Bascompte, 2006). A more regular distribution of the largest trees would also facilitate small disturbances because larger trees are more prone to such events than smaller ones (Schütz \& Saniga, 2011).

The low frequency of small groups of trees with low diameter indicated a somewhat coarser forest texture than in the random distribution. Large groups of small trees are more frequent than random, also indicating a coarse (homogeneous) structure. However, due to the small maximum size of such groups (covering less than 0.1 ha, with interspersed larger trees), this finding does not contradict with our previous conclusion of the dominance of heterogeneous stand structures. But our findings revealed a more complex stand structure than described by average patch sizes. 


\subsection{Comparing Managed and Natural Stands}

Diameter distributions make it possible to assess the stand structure of natural and managed forests with relatively little effort (Burschel \& Huss, 1997; Schütz, 2001). The DBH distributions of the three study stands reflected the differences in tree sizes between the stands completely and would provide a useful management guide for tree removals in the managed stands. However, they did not provide spatial information such as neighbourhood relationships between trees. If a closer imitation of complex natural stand structures were desired, information about this relationship would be crucial. The method presented herein could potentially support the development of more natural stand structures in managed forests.

The decrease in group numbers with increasing group size was observed in all stands, but the numbers and the decline were different. For example, the number of groups containing at least four trees of DBH $50-64 \mathrm{~cm}$ in the even-aged stand in Stauffenburg was twice that in the natural forest. The single-tree selection stand in Bleicherode more closely reproduced the observed natural stand structures. Only small differences between the number of large trees and the maximum size of tree groups were revealed. This finding demonstrates that different heterogeneous horizontal stand structures can be achieved by adequate forest management.

As mentioned in the introduction, existing quantitative methods for identifying different developmental stages in forests are mainly based on rasterization. We suggest that tree groups in beech forests develop via multiple pathways and can change their spatial arrangement over time (for example, disturbances and diameter differentiation may split a tree group). Consequently, it may be best to combine multiple methods in order to more accurately describe the complex process of forest development in natural and managed forests. For example, in previous studies different raster types were used and compared to determine the developmental stages of natural stands or the three study stands examined in this work (Tabaku, 2000; Drössler \& Meyer, 2006; Kral et al., 2014). The tree group size distributions identified in this investigation are broadly consistent with those identified using the earlier raster-based approach.

Furthermore, the success in achieving "close-to-nature" conditions could also be assessed by other indicators of forest structure, biodiversity or ecological complexity (see Zenner \& Hibbs, 2000; Pommerening, 2002; Parrott, 2010; Winter \& Brambach, 2011; von Gadow et al., 2012).

\subsection{Limitations of the Presented Method}

The method is time consuming because tree coordinates are required over study areas large enough to feature trees from all of developmental stages. Therefore, rare large-scale disturbances are difficult to address with this method (Drössler \& von Lüpke, 2005). Moreover, trees of the same size may have very different ages because beech can tolerate long periods of suppression (Piovesan et al., 2005; Kral et al., 2010; Šebkova et al., 2012) and respond strongly after release even at high ages (Leibundgut, 1993; Korpel, 1995; Schütz, 2001). This may complicate the application of the cohort concept in beech stands. However, Trotsiuk et al. (2012) found a good correlation between DBH and age $\left(r^{2}=0.8\right)$ in a natural beech forest reserve in Ukraine. In addition, it requires huge resources to determine the age of trees on such large areas, while tree sizes provide sufficient guidance for the management of uneven-aged forests (Schütz, 2001). Nevertheless, the probability of finding neighbour trees of the same size with precisely the same age in uneven-aged forest is not high, especially in older stages (Shimatani \& Kubota, 2011). Therefore, a group of trees of the same size class is not equal to a cohort sensu Oliver and Larson (1996) or others. In this respect, the even-aged stand Stauffenburg illustrates how one large single cohort can be divided into different tree groups (Figure 3, see Drössler, 2006, for single frequency values) or developmental stages (Tabaku, 2000), due to self-differentiation processes of trees.

Another drawback of the method is the large proportion of overlapping tree crowns in tree groups of different tree size classes. Drössler and Meyer (2006) found a ratio of 186\% between crown coverage (area sum of single trees) and stand area in Kyjov. Furthermore, the crown size-based definition of neighbourhood and DBH classes affects the calculation of group sizes. However, steep exponential declines of group observations with increasing group size were found for all DBH classes even in cases where enlarged radii were used to define neighbouring trees.

The exclusion of dead trees and coarse woody debris from this study ignored the possibility to explore other important links to previous forest dynamics, which can improve the relation between the evaluated forest structure and assumed disturbance history (Koop \& Hilgen, 1987).

Lastly, climate and soil conditions have effects on forest structure and dynamics. The natural forest stand examined in this work was several hundred kilometres away from the managed stands, and so may have rather 
different climatic conditions and soil. Unfortunately, this was unavoidable—-the Slovakian reserves are the closest natural stands of pure beech forest to the managed sites representing locations at sub-montane elevation. Beech forest is presumed to be the natural vegetation in the absence of human interference at sub-montane and colline elevation in Germany (Bohn et al., 2003). It is worth noting in this context that the study conducted at a second reserve in Slovakia with a different soil type yielded similar results to those reported herein for Kyjov (Drössler, 2006).

\section{Conclusions}

We provide a method for describing complex stand structures that may result from close-to-nature forest management which aims to simulate natural forest processes, to emulate natural disturbances and to increase structural diversity (Otto, 1994; Larsen, 2012). The results are based on quantitative measurements and enable comparisons to references from natural forests. Although the method generates images that can be used by managers who are aiming to develop natural stand structures, the frequency distributions of tree groups is not equal to forest developmental stages! In fact, the method is developed to complement the existing methods for studying stand structure and development.

Our results support the findings of other authors (Korpel, 1995; Tabaku, 2000; Meyer et al., 2003; Chernyavskyy, 2005; Commarmot et al., 2005) who concluded that the structure of natural beech forests was heterogeneous. Although homogeneously structured patches occur and cover areas of $400-1100 \mathrm{~m}^{2}$ (as indicated by Kral et al., 2014), they cover only a smaller proportion of the total forest area than heterogeneously structured stand sections characterized by the interspersion of smaller patches.

The results strongly support our two hypotheses: A mix of single trees dominated in different size classes in all three types of stands, and the number of tree groups decreased exponentially with increasing group size. Also, we revealed a tendency for large, single trees in natural forest to be more regularly distributed over the whole stand as suggested by random distributions.

\section{Acknowledgements}

We are grateful to Prof. M. Saniga, Prof. B. von Lüpke and Dr. P. Jaloviar for their help. We thank DFG, TC4F, the Stemmler foundation (Project Biodiversity and ecology of Slovakian beech forests), and the Southern Swedish forest research centre for financial support.

\section{References}

Bartsch, N., Bauhus, J., \& Vor, T. (2002). Effects of Group Selection and Liming on Nutrient Cycling in an European Beech Forest on Acidic Soil. In A. Dohrenbusch, \& N. Bartsch (Eds.), Forest Development (pp. 109-142). Berlin: Springer. http://dx.doi.org/10.1007/978-3-642-55663-0_3

Bauhus, J., Puettmann, K. J., \& Kühne, C. (2014). Close-to-Nature Forest Management in Europe-Does It Support Complexity and Adaptability of Forest Ecosystems? In C. Messier, K. J. Puettmann, \& K. D. Coates (Eds.), Managing Forests as Complex Adaptive Systems (p. 353). London and New York: Routledge.

Bohn, U., Neuhäusl, R., Gollub, G., Hettwer, C., Neuhäulova, Z., Schlüter, H., \& Weber, H. (2003). Karte der natürlichen Vegetation Europas. Münster: Landwirtschaftsverlag.

Brang, P. (2005). Virgin Forests as a Knowledge Source for Central European Silviculture: Reality or Myth? Forest, Snow and Landscape Research, 79, 19-32.

Brang, P., Spathelf, P., Larsen, J. B., Bauhus, J., Boncina, A., Chauvin, C., Drössler, L., Garcia-Guemes, C., Heiri, C., Kerr, G., Lexer, M. J., Mason, B., Mohren, F., Mühlethaler, U., Nocentini, S., \& Svoboda, M. (2014). Suitability of Close-toNature Silviculture for Adapting Temperate European Forests to Climate Change. Forestry, 87, 492-503. http://dx.doi.org/10.1093/forestry/cpu018

Brumme, R., \& Khanna, P. K. (2009). Functioning and Management of European Beech Ecosystems. Berlin: Springer. http://dx.doi.org/10.1007/b82392

Burschel, P., \& Huss, J. (1997). Grundriß des Waldbaus. Berlin: Parey.

Chernyavskyy, M. (2005). The Dynamics of Virgin Beech Forests in the Ukrainian Carpathians. In F. D. Hamor, \& B. Commarmot (Eds.), Natural Forests in the Temperate Zone of Europe-Values and Utilisation (pp. 100-108). Rakhiv: Carpathian Biosphere Reserve and Birmensdorf: Swiss Federal Research Institute WSL.

Commarmot, B. (2005). Structures of Virgin and Managed Beech Forests in Uholka (Ukraine) and Sihlwald (Switzerland): A Comparative Study. Forest, Snow and Landscape Research, 79, 45-56. 
Drössler, L. (2006). Struktur und Dynamik von zwei Buchenurwäldern in der Slowakei. Doctoral Thesis, University of Göttingen. http://hdl.handle.net/11858/00-1735-0000-0006-B0F2-6

Drössler, L., \& von Lüpke, B. (2005). Canopy Gaps in Two Virgin Beech Forest Reserves in Slovakia. Journal of Forest Science, 51, 446-457.

Drössler, L., \& Meyer, P. (2006). Waldentwicklungsphasen in zwei Buchen-Urwaldreservaten in der Slowakei. Forstarchiv, 77, 155-161.

Duncker, P. S., Barreiro, S. M., Hengeveld, G. M., Lind, T., Mason,W. L., Ambrozy, S., \& Spiecker, H. (2012). Classification of Forest Management Approaches: A New Conceptual Framework and Its Applicability to European Forestry. Ecology and Society, 17, 51. http://dx.doi.org/10.5751/ES-05262-170451

Ellenberg, H. (1996). Vegetation Mitteleuropas mit den Alpen. Stuttgart: Ulmer.

Finkeldey, R., \& Ziehe, M. (2004). Genetic Implications of Silvicultural Regimes. Forest Ecology and Management, 197, 231-244. http://dx.doi.org/10.1016/j.foreco.2004.05.036

Fröhlich, J. (1925). Aus dem südosteuropäischen Urwalde. Forstwissenschaftliches Centralblatt, 47, 199-206. http://dx.doi.org/10.1007/bf02420547

Gehrhardt (1923). Ueber Urwaldungen in den Karpathen. Forstliche Wochenschrift Silva, 1, 361-363.

Grassi, G., Minotta, G., Giannini, R., \& Bagnaresi, U. (2003). The Structural Dynamics of Managed Uneven-Aged Conifer Stands in the Italian Eastern Alps. Forest Ecology and Management, 185, 225-237. http://dx.doi.org/10.1016/S0378-1127(03)00217-2

Gratzer, G., Canham, C., Dieckmann, U., Fischer, A., Iwasa, Y., Law, R., Lexer, M. J., Sandmann, H., Spies, T. A., Splechtna, B., \& Szwagrzyk, J. (2004). Spatio-Temporal Development of Forests-Current Trends in Field Methods and Models. Oikos, 107, 3-15. http://dx.doi.org/10.1111/j.0030-1299.2004.13063.x

Helms, J. A. (1998). The Dictionary of Forestry. Wallingford: CABI.

Koop, H., \& Hilgen, P. (1987). Forest Dynamics and Regeneration Mosaic Shifts in Unexploited Beech (Fagus sylvatica) Stands at Fontainebleau (France). Forest Ecology and Management, 20, 135-150. http://dx.doi.org/10.1016/0378-1127(87)90155-1

Korpel, S. (1995). Die Urwälder der Westkarpaten. Stuttgart, Jena, New York: Gustav Fischer Verlag.

Kral, K., Valtera, M., Janik, D., Samonil, P., \& Vrska, T. (2014). Spatial Variability of General Stand Characteristics in Central European Beech-Dominated Natural Stands_Effects of Scale. Forest Ecology and Management, 328, 353-364. http://dx.doi.org/10.1016/j.foreco.2014.05.046

Kral, K., Vrska, T., Hort, L., Adam, D., \& Samonil, P. (2010). Developmental Phases in a Temperate Natural SpruceFir-Beech Forest: Determination by a Supervised Classification Method. European Journal of Forest Research, 129, 339-351. http://dx.doi.org/10.1007/s10342-009-0340-0

Larsen, J. B. (2012). Close-to-Nature Forest Management: The Danish Approach to Sustainable Forestry. In J. M. Garcia, \& J. J. D. Casero (Eds.), Sustainable Forest Management-Current Research. InTech. http://dx.doi.org/10.5772/30354

Leibundgut, H. (1993). Europäische Urwälder: Wegweiser zur naturnahen Waldwirtschaft. Bern, Stuttgart: Haupt.

Levin, S. A. (2005). Self-Organization and the Emergence of Complexity in Ecological Systems. BioScience, 55, $1075-1079$. http://dx.doi.org/10.1641/0006-3568(2005)055[1075:SATEOC]2.0.CO;2

Madsen, P., \& Larsen, J. B. (1997). Natural Regeneration of Beech (Fagus sylvatica L.) with Respect to Canopy Density, Soil Moisture and Soil Carbon Content. Forest Ecology and Management, 97, 95-105. http://dx.doi.org/10.1016/S0378-1127(97)00091-1

Messier, C., Puettmann, K. J., \& Coates, K. D. (2014). Managing Forests as Complex Adaptive Systems (353 p). London, New York: Routledge.

Meyer, P. (1999). Bestimmung der Waldentwicklungsphasen und der Texturdiversität in Naturwäldern. Allgemeine Forstund Jagdzeitung, 170, 203-211.

Meyer, P., Tabaku, V., \& Lüpke, B. V. (2003). Die Struktur albanischer Rotbuchen-Urwälder-Ableitungen für eine naturnahe Buchenwirtschaft. Forstwissenschaftliches Centralblatt, 122, 47-58.

http://dx.doi.org/10.1046/j.1439-0337.2003.02041.x

Müller, K. M. (1929). Aufbau, Wuchs und Verjüngung der südosteuropäischen Urwälder. Hannover: Schaper.

Muscolo, A., Bagnato, S., Sidari, M., \& Mercurio, R. (2014). A Review of the Roles of Forest Canopy Gaps. Journal of Forestry Research, 25, 725-736. http://dx.doi.org/10.1007/s11676-014-0521-7

Neumann, M. (1979). Bestandesstruktur und Entwicklungsdynamik im Urwald Rothwald/NÖ und im Urwald Čorkova Uvala/Kroatien. Doctoral Thesis, Vienna: BOKU. 
Nuske, R. S. (2006). A Retrospective Study of Canopy Gap Dynamics of a European Beech Stand. Proceedings of the International Workshop "3D Remote Sensing in Forestry”, Vienna, 14-15 February 2006, 40-44.

Oliver, C. D., \& Larson, B. C. (1996). Forest Stand Dynamics (update edition). New York: John Wiley.

Otto, H. J. (1994). Waldökologie (391 p). Stuttgart: Ulmer.

Parrott, L. (2010). Measuring Ecological Complexity. Ecological Indicators, 10, 1069-1076. http://dx.doi.org/10.1016/j.ecolind.2010.03.014

Piovesan, G., Di Filippo, A., Alessandrini, A., Biondi, F., \& Schirone, B. (2005). Structure, Dynamics and Dendroecology of an Old-Growth Fagus Forest in the Apennines. Journal of Vegetation Science, 16, 13-28.

Pommerening, A. (2002). Approaches to Quantifying Forest Structures. Forestry, 75, 305-324. http://dx.doi.org/10.1093/forestry/75.3.305

Pretzsch, H. (2009). Forest Dynamics, Growth and Yield (664 p). Berlin: Springer. http://dx.doi.org/10.1007/978-3-540-88307-4_1

Röhrig, E., von Lüpke, B., \& Bartsch, N. (2006). Waldbau auf ökologischer Grundlage. Stuttgart: Ulmer.

Runkle, J. R. (1992). Guidelines and Sample Protocol for Sampling Forest Gaps (44 p). General Technical Report PNW-GTR-283, Portland, OR: US Department of Agriculture Forest Service.

Šamonil, P., Dolezelova, P., Vasickova, I., Adam, D., Valtera, M., Kral, K., Janik, D., \& Sebkova, B. (2013). Individual-Based Approach to the Detection of Disturbance History through Spatial Scales in a Natural Beech-Dominated Forest. Journal of Vegetation Science, 24, 1167-1184. http://dx.doi.org/10.1111/jvs.12025

Schütz, J.-P. (2001). Der Plenterwald und weitere Formen strukturierter und gemischter Wälder. Berlin: Parey.

Schütz, J.-P., \& Saniga, M. (2011). Modelling the Risks of Natural Stand Closure Release with Ageing in Pure Beech (Fagus sylvatica) and Spruce (Picea abies) Stand. Annals of Forest Science, 68, 1105-1114. http://dx.doi.org/10.1007/s13595-011-0126-7

Shimatani, I. K., \& Kubota, Y. (2011). The Spatio-Temporal Forest Patch Dynamics Inferred from the Fine-Scale Synchronicity in Growth Chronology. Journal of Vegetation Science, 22, 334-345. http://dx.doi.org/10.1111/j.1654-1103.2010.01255.x

Smith, D. M., Larson, B. C., Kelty, M. J., \& Ashton, P. M. S. (1997). The Practice of Silviculture. New York: John Wiley \& Sons.

Solé, R. V., \& Bascompte, J. (2006). Self-Organization in Complex Ecosystems. Princeton, NJ: Princeton University Press.

Tabaku, V. (2000). Struktur von Buchen-Urwäldern in Albanien im Vergleich mit deutschen Buchen-Naturwald-reservaten und -Wirtschaftswäldern. Doctoral Thesis, Göttingen: University of Göttingen.

Trotsiuk, V., Hobi, M. L., \& Commarmot, B. (2012). Age Structure and Disturbance Dynamics of the Relic Virgin Beech Forest Uholka (Ukrainian Carpathians). Forest Ecology and Management, 265, 181-190. http://dx.doi.org/10.1016/j.foreco.2011.10.042

von Gadow, K., Zhang, C. Y., Wehenkel, C., Pommerening, A., Corral-Rivas, J., Korol, M., Myklush, S., Hui, G. Y., Kiviste, A., \& Zhao, X. H. (2012). Forest Structure and Diversity. In T. Pukkala, \& von Gadow, K. (Eds.), Continuous Cover Forestry, Managing Forest, Ecosystems 23 (2nd ed., pp. 29-83). Dordrecht: Springer.

Wagner, S. (1999). Ökologische Untersuchungen zur Initialphase der Naturverjüngung in Eschen-Buchen-Misch- beständen. Schriften aus der Forstlichen Fakultät der Universität Göttingen und der Niedersächsischen Forstlichen Versuchsanstalt. Band 129. Frankfurt: Sauerländer, J D.

Winter, S., \& Brambach, F. (2011). Determination of a Common Forest Life Cycle Assessment Method for Biodiversity Evaluation. Forest Ecology and Management, 262, 2120-2132. http://dx.doi.org/10.1016/j.foreco.2011.07.036

Zeibig, A., Diaci, J., \& Wagner, S. (2005). Gap Disturbance Patterns of a Fagus sylvatica Virgin Forest Remnant in the Mountain Vegetation Belt of Slovenia. Forest, Snow and Landscape Research, 79, 69-80.

Zenner, E. K., \& Hibbs, D. E. (2000). A New Method for Modeling the Heterogeneity of Forest Structure. Forest Ecology and Management, 129, 75-87. http://dx.doi.org/10.1016/S0378-1127(99)00140-1 